\title{
Eve Warburton
}

\author{
RESOURGE NATIONALISM IN INDONESIA: \\ OWNERSHIP STRUGTURES AND SEGTORAL \\ VARIATION IN MINING AND PALM OIL
}

\begin{abstract}
During the global commodities boom Indonesia, like many resource-rich countries, introduced an increasing number of nationalist policy interventions. However, the state has intervened assertively in some sectors and only passively in others. In Indonesia's mining sector, interventions that compel foreign divestment received widespread support from politicians and domestic industry; yet similar proposals to limit foreign investment in the strategic agribusiness sector have largely failed. This article brings the literature on resource nationalism into conversation with studies of business-state relations, in order to understand why nationalist mobilization met with more success in Indonesia's mining sector than in agribusiness. It argues that ownership structures constitute the source of this variation. Uniquely integrated patterns of domestic and foreign ownership in the strategic palm oil sub-sector constrained lawmakers' nationalist agenda. Such constraints were less formidable in Indonesia's mining sector, where foreign capital is more easily differentiated, and concentrated in a sub-sector that contributes less overall to the Indonesian economy.
\end{abstract}

\section{Keywords}

Indonesia, natural resources, political economy, resource nationalism, mining, palm oil

\section{INTRODUCTION}

During the global commodity boom from 2000 to 2014 , Indonesia became known as a country marked by "resource nationalism." International industry publications, media, and scholarly analyses regularly commented on a general trend toward greater state control of resource extraction and increased limitations on foreign investment. The government introduced a wide mix of policy prescriptions, including divestment requirements for foreign companies, increases in taxes and royalties, and restrictions on the export of unprocessed raw commodities. It seemed, therefore, that Indonesia represented a typical case of resource nationalism according to the dominant market-cycle explanation, which argues that high commodity prices trigger a nationalist response from state policymakers.

However, a closer examination shows that the state has been assertive and interventionist in some sectors, but relatively passive in others. More specifically, the government legislated to limit foreign investment in the mining sector, while in the plantations sector similar proposals largely failed. During deliberations over the 2009 Mining Law, 
legislators successfully pressured the government to increase the divestment obligations of foreign companies, arguing that Indonesians should have a larger share in their country's natural resource economy. Within 12 months, the government introduced an implementing regulation that mandated foreign companies to divest 20 percent ownership of their projects by the fifth year of operation. In 2014, the government went further by compelling companies to divest 51 percent by year ten. In that same year, parliament proposed that a new plantations law include a cap on foreign investment in all plantations, including the booming palm oil sub-sector. Legislators framed their proposition in the same nationalist terms, and foreign observers feared resource nationalism was spreading from mining to agribusiness (McBeth 2014). In the final stages of the law's negotiation, however, the executive threw out the proposed cap.

What explains this variation? Why do we find assertive nationalist intervention in Indonesia's mining sector, and only muted attempts to limit foreign ownership in the plantations industries? What motivates and constrains state intervention in Indonesia's resource markets, and why do outcomes vary at the sector level? In this article I argue that, in Indonesia, resource nationalism is contingent not simply upon a price mechanism or state-level institutions, as much of the literature suggests, but also upon the structure of ownership - who owns what, how much, and in what sub-sectors-in a given sector. Specifically, I argue that the organization of domestic and foreign ownership at the sector level matters for whether lawmakers realize their nationalist policy goals.

The mining sector in Indonesia is characterized by a polarized ownership structure, whereby foreign and domestic capital are differentiated, and the largest mineral and coal producers have relatively clear shareholder structures that demonstrate either domestic or foreign control. Consequently, foreign capital represents a distinct and readily targeted component of the industry, and prominent domestic businesses had a preference for anti-foreign intervention in order to expand their own investments. The palm oil sub-sector, which dominates Indonesia's plantations industry, is characterized by an integrated ownership arrangement in which Malaysian, Singaporean, and Indonesian corporate interests are closely intertwined. Interdependent ownership structures meant nationalist interventions conflicted with the interests of Indonesia's wealthiest tycoons. As a result, powerful domestic businesses opposed efforts to introduce restrictions on foreign investment.

In addition, foreign investors' relative contribution to the mining industry overall has been decreasing over time, and the divestment obligations in the 2009 Mining Law targeted large multinational companies whose investments are primarily in hard rock and precious mineral extraction. This sub-sector makes a substantial, but not major, contribution to Indonesia's overall economy. Thus, lawmakers were less concerned about the larger economic ramifications of a new divestment regime.

In the plantations sector, the opposite was true. Foreign investment has increased over the past 15 years in the dominant palm oil sub-sector, and is uniquely integrated with local capital networks. The sub-sector is also more strategic than precious minerals in terms of contribution to GDP, foreign exchange and employment. The risk of alienating both foreign and domestic capital constituted a broader danger to the economy, and the executive feared the economic repercussions of a new cap on foreign investment. In the strategic oil palm sub-sector, therefore, integrated ownership structures constrained lawmakers' nationalist agendas. 
In summary, the analysis presented here suggests that ownership structures have implications for the form and fate of nationalist interventions in two ways: first, they shape the policy preferences of domestic business, and second, they constitute a structural constraint upon state actors' capacity to limit foreign capital. Where domestic and foreign ownership is polarized and differentiated, state actors are better able to target companies for nationalist interventions, and domestic businesses will support nationalist legislation; where domestic and foreign capital are integrated and interdependent, as in Indonesia's palm oil sub-sector, local business interests are unlikely to support nationalist interventions. Additionally, to the extent that states must appeal to foreign investors in order to achieve growth outcomes, foreign capital constitutes a 'structural' constraint upon lawmakers' freedom to design and implement a range of policies (Haggard, Maxfield, and Schneider 1997; Winters 1996). In Indonesia's palm oil sub-sector, structural constraints upon nationalist interventions are much stronger because integrated flows of private foreign and domestic capital make major contributions to what is an economically vital resource industry.

Methodologically, this article departs from much of the comparative literature on resource nationalism, and economic nationalism more generally. Most studies compare differences between countries, and presuppose that state-level institutions explain the presence or absence of anti-foreign or protectionist policies. The literature generally overlooks variation within a single country. In this study, I hold nationallevel conditions constant and draw upon the classic "method of difference approach" (George and Bennett 2005, 153-157). I offer a structured comparison of two commodity sectors in one country that share a set of similar characteristics, which make them ripe for nationalist mobilization: both mining and agribusiness are strategic economic drivers of the Indonesian economy, both experienced price booms, both are key destinations for foreign investors, production is concentrated around a group of large firms in both industries, and both sectors were targeted for legislation that would limit foreign investment. However, nationalist outcomes varied. Anti-foreign mobilization met with comparatively greater legislative success in the mining sector than in plantations. My analysis suggests that distinct ownership structures constitute the source of this variation.

The article is arranged as follows. After this introduction, the second section situates the Indonesian case within the contemporary literature on resource nationalism, and explains the intellectual antecedents and key assumptions of that literature. To help analyse the Indonesian case, I bring the literature on resource nationalism into conversation with political economy studies of industrial policy and business-state relations, in which scholars examine how ownership patterns and business preferences shape policy outcomes at the sector level. The third section sets up the comparative analysis, explaining how, in the context of booming commodity prices, lawmakers tried to introduce restrictions on foreign ownership in both the mining and plantations sectors-but legislative outcomes varied. In the fourth section I provide a detailed discussion of ownership structures in each sector and their implications for nationalist interventions. I draw upon legislative debates, parliamentary records, and interviews with lawmakers, politicians, and industry representatives, combined with data on corporate ownership in both sectors. The conclusion reflects upon what my analysis contributes to the study of nationalist interventions in Indonesia, and to the study of resource nationalism more broadly. 
EXPLAINING RESOURCE NATIONALISM: BOOMS, INSTITUTIONS, AND OWNERSHIP STRUCTURES

The contemporary literature on resource nationalism frequently cites Indonesia as an example of the phenomenon. Yet the arguments advanced in this body of work can provide only a partial account of how and why resource nationalism has emerged in Indonesia. This literature generally looks to price booms and state-level institutions in order to explain the rise of resource nationalism, and why it takes hold in some countries and not others. Existing studies rarely focus upon intra-state variation and sector-level differences. In order to help explain cross-sectoral variation in nationalist policy within a single country such as Indonesia, I suggest the political economy literature on comparative industrial policy and state-business relations can offer fresh analytical tools. Specifically, these bodies of work show how businesses constrain state policy directly through lobbying the state to realize their regulatory preferences, and indirectly through making investment decisions that impact upon economic growth. Businesses constrain policymakers differently in different sectors, and their influence on policy outcomes can depend upon the particular features of a given sector. In Indonesia's mining and plantation sectors, I argue, distinct ownership structures produced divergent business preferences and distinct structural constraints with regard to lawmakers' nationalist agendas, which in the end produced varied nationalist outcomes.

In the broadest sense, resource nationalism refers to state intervention in natural resource industries in order to exert more control over the terms of private investment. In this article, I use the term 'nationalist intervention' to refer to formal policies or legislation, while 'nationalist mobilization' refers to efforts (public campaigns, court cases, proposed legislation, and the like) made by state and non-state actors in pursuit of formal nationalist policies. Nationalist interventions target private capital, and usually foreign capital, in particular, and can range in form from the nationalization of foreign assets, restrictions on foreign investment, to less contentious initiatives that increase taxes and royalty payments (J. Wilson 2015; Haslam and Heidrich 2016b). Analyses of resource nationalism favor a conventional market-cycle explanation that perceives resource nationalism to be a function of high commodity prices (Bremmer and Johnston 2009, 149; Benjamin 2013; Smither 2013; Minto 2012; Stainslaw 2010; Chikwanha 2012). The logic is twofold: first, boom times provide governments of resource-rich countries greater leverage in their negotiations with foreign investors and more influence over international commodity markets (Humphreys 2013; Herberg 2011); second, there is more money to be made during a boom, which motivates (often corrupt) state officials and politically connected business groups to seek greater access to resource rents via state intervention (Solomon 2012; Kurtz and Van Zorge 2013; Stevens 2008; Weiner and Click 2009).

The market-cycle explanation reflects much earlier scholarship on the energy sector and the programs of nationalization in Middle Eastern and Latin American countries from the 1950s through to the booms of the 1970s and 1980s. Ernest Wilson (1987) argued that a "petro-political cycle" exists, whereby booms produce "industrial radicalism," or extensive state interventionism, amongst petroleum exporting states because of the leverage they gain over companies and importing states. Vivoda's $(2009,519)$ more recent analysis of international oil companies' bargaining power similarly argues that 
resource nationalism is "a by-product of high prices." According to this perspective, resource nationalism is epiphenomenal, rising in tandem with commodity prices and producing similar responses across resource rich countries. ${ }^{1}$

However, a nascent body of comparative scholarship on resource nationalism argues that while state intervention might increase in the context of high commodity prices, booms cannot explain variation in the types of nationalist interventions that have appeared in resource rich countries around the world. Analysts are therefore beginning to explore how countries respond to booms in different ways, and to note that expressions of resource nationalism are not uniform (Domjan and Stone 2010; Gardner 2013; J. Wilson 2011). The typical approach is to compare differences between countries. One emerging line of argument emphasizes the role played by states' distinct political and economic institutions (Arbatli 2013; J. Wilson 2015; Haslam and Heidrich 2016b; Frieden 1991). According to Wilson (2015), for example, states with a liberal-capitalist institutional orientation will generally limit their policy interventions to those that aim to capture rent, such as tax increases. States with a stronger leftist or developmentalist tradition, including Indonesia, Wilson argues, will exhibit a preference for policies that exert state control over company activities, like mandating local content or downstream processing. Wilson offers a parsimonious and powerful explanation for cross-country variation, but the framework is less useful for understanding why a single state might behave differently in different sectors.

One study draws attention to the role of sector-level factors. Haslam and Heidrich (2016a) compare resource nationalism in several Latin American countries and argue that, alongside national political institutions and global market forces, specific industry variables matter for explaining different types of nationalist interventions across countries. For example, where a natural resource industry dominates a country's economy, or where the size of proven mineral reserves is particularly large, resource nationalism is likely to be more assertive because the incentives are higher. The authors also touch upon - though do not explore in-depth-how the capacity of domestic capital might constrain a state's ability to enact nationalist legislation. In countries where the local business class has only limited capital, there exist few alternatives to foreign investment. In such circumstances, "governments must be careful not to alienate foreign investors" (Haslam and Heidrich 2016a, 229), and thus tend not to introduce assertive anti-foreign regulations, even during boom times. Their point here speaks to how foreign capital can constitute an indirect, structural constraint upon lawmakers and their nationalist agendas. While not offering an explicit analysis of intra-state variation, their study argues that sector-level factors matter and help explain variation.

In sum, the contemporary comparative literature on resource nationalism has so far overlooked the diversity of nationalist practices that are evident within a single country. Generally speaking, it fails to ask what might make nationalist intervention more appealing and widespread in some sectors of an economy than in others. Accordingly, in this article I ask why Indonesia has experienced more restrictions upon foreign ownership in the mining sector compared with the booming palm oil sector, where foreign investment plays a prominent role and where, historically, the government has been willing to legislate limitations on foreign companies. What factors enable and constrain Indonesian lawmakers' capacity to intervene in different parts of their economy? 
Studies on Indonesia specifically also offer only limited answers to such questions. Most academic studies of the Indonesian case are limited in scope, focusing on technical changes to the mineral mining industry (Bahsin and Venkataramany 2008; Junita 2015; Cabello et al. 2013), while most scholarship on Indonesia's palm oil sector focuses on land and environmental governance issues and conflicts between corporations and smallholder farmers (Obidzinski et al. 2012; J. McCarthy 2012; J. McCarthy 2010). Public commentary on Indonesia's resource nationalism tends to be critical, with analysts attributing nationalist policies to myopic, under skilled bureaucrats and rent seekers (The Economist 2012; Kurtz and Van Zorge 2013; Castle 2014; Mattangkilang 2012; Manning and Purnagunawan 2011; Garnaut 2015; Schwarz 2013; McBeth 2014). ${ }^{2}$ Scholars of Indonesia's economy also highlight policy makers' penchant for economic nationalism, and suggests that governmental institutions are imbued with a statist ideology and suspicion, even antagonism, toward foreign capital (see for example Soesastro 1989; Bresnan 1993; Hill and Basri 2004). However, rent seeking, bureaucratic myopia, and nationalist ideologies feature prominently in many parts of Indonesia's economy. Highlighting such factors does not help to isolate the sources of sectoral variation.

In this article I suggest that it is ownership structures that play the pivotal role in determining nationalist outcomes in each sector. First, ownership structures constrain nationalist interventions through shaping businesses' policy preferences. Comparative political economy studies of state-business relations examine how the private sector constrains or enables governments in realizing their economic agendas (Evans 1995; Maxfield and Schneider 1997). ${ }^{3}$ One of the most direct ways that businesses exert pressure upon lawmakers is through organized appeals to the state to enact preferred policies (Haggard, Maxfield and Schneider 1997). The private sector's policy preferences are necessarily dependent upon the particular features of a sector or sub-sector-for example, the required capital investments for production, reliance upon foreign investors, the technological complexity of an industry, concentration and size of companies, and so forth. For this reason, scholars argue that business preferences are 'sectorally determined' (Shafer 1990; 1994; Frieden 1991) and can be compared across different sectors between or within countries (Wright 1988; Atkinson and Coleman 1989; Kitschelt 1991; Shafer 1990; 1994; Frieden 1991; Hsueh 2012; 2016).

Most literature on resource nationalism, however, assumes that booms produce a coherent and overlapping set of preferences amongst state and domestic corporate actors in favor of anti-foreign policies. But in the Indonesian case, as we shall see, preferences diverged at the sector level. I argue that distinct ownership structures in each sector produced different industry preferences. In the mining sector, where foreign and domestic capital are polarized and differentiated, and prominent domestic companies have the capacity to expand their market share, local business demonstrated a preference for anti-foreign legislation. Meanwhile, in the palm oil sector, where foreign and domestic capital are uniquely integrated, companies opposed a regulatory change that would limit foreign investment.

A brief caveat: my analysis does not identify the "organization" of business as an important source of policy variation between these two sectors. Indeed, the aggregation of private sector interests in Indonesia's mining and plantations sectors, and the approach to lobbying policymakers, display more similarity than difference. In both sectors, business associations tend to be fragmented and weak. Instead, as is the case in Indonesia 
more generally, business-state relations in both sectors are constituted primarily through informal networks and personalized relations between corporate actors and the political and bureaucratic elite (Chua 2008; Hamilton-Hart 2015; Davidson 2016). Thus, in both sectors, industry associations made formal appeals to the government regarding nationalist legislations, but observers perceive the informal lobbying of major domestic businesses as having the most sway over policy outcomes.

The second part of my argument is that patterns of domestic and foreign ownership indirectly constrain lawmakers' capacity to enact anti-foreign legislation-even during a commodity boom. One important insight from the literature on state-business relations is that private capital need not always be organized, or actively lobbying the state, in order to exert pressure upon government decision-makers. State actors are inherently constrained by the actions and reactions of private capital, because levels of investment — and foreign investment specifically_contribute directly to a country's economic health (Haggard, Maxfield and Schneider 1997, 38). For example, in his study of capital mobility in Indonesia, Winters $(1996,2)$ argues that, "investors' decision are of enormous consequence for societies and leaders of state," which gives them immense "structural political power" and an implicit say over how state actors regulate their economy. Haggard, Maxfield and Schneider $(1997,38)$ agree, and assert that, "capital votes twice: once through organized pressure it can bring to bear on the political process, again through its investment decisions."

Private capital represents a particularly powerful structural constraint in strategic sectors that make large contributions to GDP, foreign exchange earnings, as well as to local employment. Thus, to the extent that foreign investment plays a large role in an economically strategic resource sector, lawmakers will be more constrained in their capacity to target and limit foreign capital, even under boom conditions. As we shall see, most foreign investment in Indonesia's mining industry flows into the lucrative-but overall less economically strategic-precious minerals sub-sectors like gold and copper. In the plantations industry, the majority of foreign capital flows into the palm oil sub-sector. Nationalist intervention into palm oil presented a greater economic risk, because foreign and domestic capital are both are crucial to maintaining the sector's production levels and its contribution to the Indonesian economy.

Before proceeding, a brief note on case selection is necessary. Studies of resource nationalism are most often concerned with extractive industries (oil, gas, and mineral mining). Scholars assume extractives are particularly vulnerable to state intervention, rent seeking, and protectionist mobilization because they are a non-renewable, capital intensive, and geographically concentrated-otherwise known as a 'point source' resource (Isham et al. 2005). However, studies of natural resource economies regularly place cash crops and agribusiness industries in the same analytical category as extractives, and suggest both industries suffer boom-bust vulnerabilities and are subject to similar patterns of rent seeking and protectionist intervention during a boom (Boschini, Pettersson, and Roine 2007; Isham et al. 2005; Ross 2001). ${ }^{4}$ There is nothing inherent to the agribusiness sector that makes it immune to nationalist intervention, and foreign ownership is highly contested in agricultural economies around the world. Indeed, Indonesia's palm oil sub-sector was closed to foreign investors on and off throughout the 1990s. In other countries, such as Argentina and Brazil, the global boom in commodities prompted anti-foreign interventions in both the extractives and agribusiness sectors 
(Oliviera 2013; Perrone 2013; Fairbairn 2015). For these reasons, comparing anti-foreign interventions in Indonesia's palm oil and mining sectors is a reasonable analytical enterprise and an empirically important one.

\section{NATIONALIST MOBILIZATION IN THE MINING AND PLANTATIONS SECTORS: COMPARING DIVERGENT OUTCOMES}

Indonesia is a major natural resource exporter on global markets, and it benefitted greatly from the commodity boom. China's rapid economic expansion produced a seemingly insatiable demand for the world's coal, nickel, iron ore, palm oil, and other raw commodities. As a result, according to the World Bank, between 2002 and 2012 the "global energy nominal price index (coal, crude oil and natural gas) increased four-fold; the metals and minerals nominal price index increased three-fold; the precious metals (including gold) index increased six-fold; and agricultural commodities such as CPO [crude palm oil] increased three-fold" (World Bank 2015). Indonesia is the world's leading producer of palm oil, the second largest for thermal coal, and amongst the world's top producers of nickel, tin, gold, copper, and bauxite (Cabello et al. 2013).

The plantations and mining sectors have played a crucial role in Southeast Asia's largest economy, driving impressive growth for ten years from 2004. During these boom years, mining and agriculture's share of total exports increased, while the share of manufacturing decreased steadily (Elias and Noone 2011). After petroleum, coal is Indonesia's second largest source of foreign exchange from exports, earning the state 22.9 billion USD in export income in 2013 (Casson, Muliastra, and Obidzinski 2015). Palm oil is the third largest foreign exchange earner for the government and in 2013 CPO exports were valued at USD 19.2 billion (Casson, Muliastra, and Obidzinski 2015). As Table 1 illustrates, the mineral sub-sectors of copper and gold, which are the target of much nationalist intervention and mobilization, contribute less to foreign

TABLE 1 Percentage contribution of natural resources to exports and GDP in 2012

\begin{tabular}{lcc}
\hline \hline Commodity & Exports $^{\mathrm{a}}$ & Share of GDP $^{\mathrm{b}}$ \\
\hline Energy Commodities & 31.0 & 10.7 \\
Crude oil & 6.5 & 7.8 \\
Natural gas & 10.8 & \\
Coal & 13.8 & 4.2 \\
Non-energy commodities & 7.5 & 5.8 \\
Gold & 1.2 & 0.4 \\
Nickel & 1.3 & 0.4 \\
Copper & 1.4 & 0.3 \\
Bauxite & 1.2 & 0.1 \\
Tin & 1.2 & 0.08 \\
Agricultural Commodities & 12.5 & 13.8 \\
Crude palm oil (CPO) & 6.5 & $2.5^{\mathrm{c}}$ \\
TOTAL & 53.8 & 37.3 \\
\hline \hline
\end{tabular}

Note: (a) World Bank 2015, 39. (b) Breakdown for each extractive sector commodity is taken from: "Scoping Study on the Reconciliation of Oil, Gas and Mining Financial Flows 2012-2013" (Extractive Industries Transparency Initiative, 2015). (c) Mark Henstridge, Sourovi De, and Maja Jakobsen, "Growth in Indonesia: Is it Sustainable" (Oxford Policy Management, 2013). 
exchange and less to GDP as well. Table 1 also shows how at the height of the boom in 2012 natural resource industries made up 53.8 percent of Indonesia's exports and 37.3 percent of GDP. It is, therefore, critical that we understand what drives changes to these sectors' investment regimes.

\section{ASSERTIVE RESOURCE NATIONALISM IN THE MINING SECTOR}

During the boom years, Indonesia's mining industry became subject to an increasing number of nationalist policies. These interventions were associated with the 2009 Mining Law, which industry observers regularly cite as evidence of Indonesia's turn to resource nationalism. ${ }^{5}$ The Law introduced a new licensing system, which gave the state more control and discretion throughout the life of long-term extractive projects and adjusted the regulations on royalties and divestment. ${ }^{6}$ The 2009 Mining Law and its implementing regulations also mandate that mining companies engage more domestic content in their business, which means that companies must employ domestic mining services companies over foreign ones and, where possible, purchase locally produced goods (Budiman 2011). Details of this nature had previously been worked out between the company and the government through individual Contracts of Work (CoW). Introduced in 1966 by the Suharto Government, the CoW system was designed to more easily attract foreign mining companies in the context of a devastating economic recession. To this end, President Suharto signed the first $\mathrm{CoW}$ with American mining company Freeport McMoRan in 1967 for the Ertsberg deposit in Papua. The government was in a poor bargaining position, and Freeport drew up a contract with remarkably attractive terms for the company.

By the early 2000s, commodity prices were rising steadily and the government and parliament became increasingly sensitive to the fact that big foreign miners, in particular Freeport and Newmont (another prominent American gold and copper mining company), were benefitting hugely. While Freeport operates one of the largest and most profitable gold mines in the world, the company had divested only 9 percent of its operations to domestic entities since opening the mine in $1967 .{ }^{7}$ So in 2007 , with a new bill before them, the government and parliament took the opportunity to rethink the terms of investment for foreign companies. The original draft of the Mining Law presented by the Ministry of Energy and Mineral Resources (MoEMR) to parliament had no clause on mandatory divestment (Investor Daily 2007). ${ }^{8}$ The Ministry's idea was that under the new licensing system, foreign companies would be compelled to partner with state owned companies and majority owned Indonesian companies, thus negating the need for divestment.

However, parliamentarians took the bill in a more radical direction. Several political parties in parliament argued that even under the new licensing system, foreign companies should be subject to divestment obligations (Investor Daily 2007). Nationalist legislators, particularly those from the prominent then opposition party, Indonesian Democratic Party-Struggle (PDIP), pressured the government to cancel the contracts of companies like Freeport, Newmont, BHP, and issue them licenses under the terms laid out in the new law, including new and more stringent divestment requirements. ${ }^{9}$ A former Director General of Mineral and Coal Mining who worked on the law commented that parliamentarians were constantly trying to push the government down a more nationalist path, wanting always to prove themselves to the public and senior leaders of their parties. 
Indeed, parliamentarians themselves talked about the pressure they felt to demonstrate nationalist credentials to voters. The Director General said the government had to compromise: "what could we do? ... Indonesia is a democracy, and more people now have a say in how resources are controlled."10

The government resisted parliamentarians' calls to cancel contracts, but it accepted the proposal that foreign companies already operating in Indonesia should undertake more divestment, and therefore agreed to include an article compelling existing CoW companies to relinquish more control to local parties. ${ }^{11}$ To this end, Article 112 of the 2009 Mining Law mandated new divestment requirements with the aim of boosting the market share of state owned and domestic private companies at the expense of foreign investors. It outlined that after five years in operation, foreign mining projects must begin to divest, offering shares first to the government, then state owned enterprises, followed by domestic companies. Government and state-owned enterprises were given priority under law; however, their limited capital and capacity meant that private players were set to reap the benefits of divestment more than state entities. In some cases, private companies established partnerships with local governments in order to gain priority access to foreign shares. ${ }^{12}$

The industry was divided. The Indonesian Mining Association (IMA) and the Indonesian Coal Mining Association (ICMA), the most prominent industry bodies, initially disagreed with the divestment obligations-they were concerned about what impact divestment might have on the sector's development. IMA and ICMA represent both domestic and foreign companies, and they felt the legislation not only hurt the interests of their foreign members, but also created a mood of regulatory uncertainty and hostility that would spook future investment. The foreign mining industry was vehemently opposed, and companies made regular appeals to the government to retract the divestment obligation, lest foreign companies begin pulling out of Indonesia. The Association of Indonesian Mining Professionals (Perhimpungan Ahli Pertambangan Indonesia, or Perhapi) represents solely Indonesian industry voices, and expressed similar concerns about the mining bill's impact on the investment environment in general, but took no strong public position either way on the divestment obligations. ${ }^{13}$

Meanwhile, other Ministries and leading figures within the Yudhoyono government were strongly opposed to the new divestment regime. The Ministry of Trade reportedly heard little about the bill's content and had not been briefed on the proposal to limit foreign investment. Then Trade Minister Mari Pangestu disagreed with the new divestment and local content obligations, because Article 112 clashed with the spirit and letter of the 2007 Investment Law. ${ }^{14}$ Pangestu was intimately involved in designing the Investment Law, which removed restrictions on foreign investment and was intended to have jurisdiction over all ministries. Senior bureaucrats within the sectoral ministries, particularly those with jurisdiction over natural resources, disagreed with the openness of the Investment Law. As a result, from around 2009 parliament and various ministries began introducing bills that tried to undermine the Trade Ministry's influence on foreign investment.

Despite opposition from many quarters, the law was passed, and MoEMR proceeded to introduce several implementing regulations that detailed and adjusted the conditions of divestment. In 2010 the MoEMR released an implementing regulation for Article 112, which outlined that foreign companies must divest 20 percent of their business after 
five years of production. The 20 percent figure came out of consultations with industry associations, and both state officials in the Ministry and industry representatives were reportedly satisfied with this result. ${ }^{15}$ While initially opposed to the changes, after years of negotiations IMA and ICMA came to accept that divestment obligations would be part of the new law and focused their efforts on lobbying for an acceptable level of foreign divestment. In the negotiations leading up to the 2010 regulation, IMA agreed that 20 percent was a reasonable figure, and "still acceptable" to foreign investors (The Jakarta Post 2009). So the industry was shocked when the government changed the rules again in 2012. A new regulation compelled foreign companies to divest the majority of their assets, 51 percent, by the tenth year of production (Article 97 clause (1a) of Government Regulation No.24/2012). Two years of fraught contract negotiations ensued between the MoEMR and foreign mining companies.

In 2014, the new administration of President Joko Widodo (2014-) flirted with a more conciliatory approach to the foreign mining sector. The government changed the regulation so that divestment levels were contingent upon the type of mining activity in which a foreign company was engaged (Junita 2015). For example, miners like Freeport that were engaged in more technical and capital-intensive underground mining, were only required to divest 30 percent to local parties. But just two years later, in January 2017, the government reversed that regulation and reinstituted the 51 percent requirement, preparing the groundwork for a local takeover of Freeport's Grasberg mine, one of the most lucrative copper and gold deposits in the world.

In sum, at the height of the boom the Indonesian government, in negotiation with the parliament, drafted a new mining law. In the context of rising prices and corporate profits, both parties agreed to target large foreign companies and create more space for state and domestic companies. Despite opposition and pressure from the foreign mining industry, formal opposition from several peak industry bodies, and staunch criticism from international business analysts, the legislation was passed and a series of implementing regulations quickly followed. These regulations became increasingly nationalist, even after the boom had come to an end.

MUTED RESOURCE NATIONALISM IN THE PLANTATION SECTOR

In the plantations sector, similar proposals to restrict foreign investment largely failed. The Ministry of Agriculture (MoA) worked with the parliament to develop a new Plantations Bill in early 2014. The bill mandated a cap of 30 percent foreign shareholding in any plantation company operating in Indonesia (Hukum Online 2014). This article directly contradicted the 2007 Investment Law and the Negative Investment List, which stipulated that foreign investors can own up to 95 percent of an agricultural plantation conditional upon recommendation from the Ministry of Agriculture. The new draft also outlined that joint ventures between domestic and foreign companies must keep their funds in Indonesian banks, and the foreign companies engaged in a joint venture must ensure a transfer of technology to the local partner, plus adhere to strict local content requirements (Hukum Online 2014). While the bill was designed for the entire plantations industry, it appeared to target the lucrative palm oil sub-sector where foreign capital constitutes a far greater share of investment than in other plantation sub-sectors 
such as rubber or cacao, were over 85 percent of production is by independent smallholders (Arifin 2013).

The new bill's emphasis on local ownership was primarily the work of Parliamentary Commission IV on Agriculture, Forestry, Food and Maritime Affairs, rather than the government. It appears that, as was the case with the 2009 Mining Law, the Indonesian Democratic Party-Struggle (PDIP) played a leading role in pushing for greater restrictions upon foreign investment. ${ }^{16}$ However, parliamentary records also highlight strong support from one of the prominent Islamic parties, the National Mandate Party (PAN) (Parliament Plenary Session Report, September 29, 2014). The Deputy Chairman of the Commission, Herman Khaeron of the Democrat Party, also made impassioned public statements about the critical need to curb foreign ownership of Indonesia's plantations, and "protect the nation's natural resources for the people" (Info Sawit 2014). In a parliamentary media publication, Khaeron explained that the 30 percent limitation on foreign investment was necessary, "because we want our community's livelihoods and their aspirations be realized by the government, and for the government to ensure the Indonesian people's prosperity" ("Buletin Parlementaria" 2014).

International media and the palm oil industry were quick to decry the proposal, and claimed resource nationalism from the mining sector was spilling over into agribusiness (Adnan 2014; Zadek et al. 2014; Beckmann and Rakhmatillah 2014; McBeth 2014). Those who worked on the law also said inspiration came in part from changes in the mineral mining sector. ${ }^{17}$ Indeed, lawmakers in both cases used remarkably similar rhetorical justifications. When it came to plantations, lawmakers argued that foreign capital benefitted too much from the exploitation of Indonesian land and its most strategic commodities, at the expense of domestic companies and small famers (Global Business Guide 2014). The same parliamentary commission had also recently introduced a new Horticulture Law, which included a similar cap on foreign investment, and lawmakers felt the same logic should be applied to plantations where foreign ownership was in fact much higher. ${ }^{18}$

While the proposed cap on foreign investment may have originally emerged from parliamentarians, the clause reflected a general nationalist thrust in the Ministry's policy goals. The MoA laid out a strategic plan for 2009-2014 that emphasized food and agricultural independence, and prioritized local produce over imports (Patunru and Rahardja 2015; Ministry for Agriculture 2009). The minister at the time, Suswono, was a senior member of the Prosperous Justice Party (PKS), a conservative Islamic party known for taking a nationalist position on resource issues generally, and whose faction in Commission IV supported the foreign investment cap. Some industry elites speculated that Suswono personally approved the idea of legislating the cap on foreign investment, but he was ultimately pressured by other members of the executive to resist the parliament's proposal.

This was not the first time the government had tried to facilitate more local ownership in the palm oil sector. In 2013, a ministerial regulation outlined that all private palm oil companies collaborating with farmers' cooperatives should divest a minimum of 30 percent of shares to the cooperative after 15 years (Ministry of Agriculture Regulation 98/2013 on Plantation Licensing). The regulation was intended to empower local farmers. By most accounts, however, there was no attempt to enforce the new policy. Companies and those active in the industry had little knowledge of the regulation and 
showed little concern for its consequences. ${ }^{19}$ Moreover, by 2014 the Ministry's energy was focused on the contents of the new law, so little effort appears to have been made to monitor or enforce the 2013 regulation.

Once the proposed cap became public knowledge, Indonesia's Palm Oil Industry Association (GAPKI) and the largest palm oil companies within it began a swift campaign to have the 30 percent limitation removed from the bill, and to eliminate any reference to joint ventures keeping their finances in domestic banks. ${ }^{20}$ These companies were not only acting on behalf of their foreign members, but also on behalf of prominent domestic companies which also opposed the bill and backed GAPKI's efforts to have the investment restrictions dropped. According to GAPKI, the executive listened to the business community's warnings that divestment would not only deter future investors but would also devalue the price of Indonesia's land and reduce CPO production. ${ }^{21}$

Thus, when the bill was signed into law, in September 2014, the offending paragraphs had already been dropped. The final version outlines in only the most general terms that foreign investment levels will be detailed in future government regulations. Paragraphs mandating plantation companies to engage in domestic processing, and emphasizing technology transfers and local content requirements, were also dropped. According to some reports, these items were only removed from the bill after President Yudhoyono intervened (McBeth 2014). ${ }^{22}$ The minister and the parliament were at pains to assure the public that caps on foreign ownership would be implemented via ministerial regulations in the near future (Raykat Merdeka Online 2016). However, such regulations require political will on the part of the ministry to speed up design and implementation. At the time of writing - almost three years since the law was introduced—no such regulations have materialized and the issue has fallen off the Ministry's agenda. ${ }^{23}$

Why did the parliament and MoA's attempt to shift the laws around foreign ownership and local content receive such little support from domestic industry and from executive government, particularly when similar legislation had passed in other sectors?

OWNERSHIP STRUCTURES AS CONSTRAINTS UPON NATIONALIST POLICY AGENDAS

\section{THE MINING SECTOR}

The mining sector's polarized ownership structures presented opportunities for nationalist intervention. The majority of foreign investment in the mining sector is in precious mineral extraction, and the companies that invest, produce, and profit the most in this sub-sector are foreign owned and have been slow to facilitate domestic shareholding. These ownership features make foreign mining companies a target for nationalist policymakers and local businesses. Lucrative foreign mineral mines have become a soughtafter prize for Indonesian tycoons, and so domestic business preferences dovetailed neatly with the nationalist agenda of state bureaucrats and politicians. In addition, because metallic and precious minerals make only a moderate contribution to Indonesia's overall economy, particularly in comparison to other commodities like coal and palm oil, foreign capital constituted less of a constraint upon lawmakers' nationalist agenda.

The structure of ownership in Indonesia's mining sector has been changing rapidly over the past two decades. During the New Order, the country's tycoons built their 
empires in the timber, plantations, tobacco, property, food, retail, and finance industries (for a description of Indonesia's conglomerates and their evolution, see Mackie 2003; Carney and Hamilton-Hart 2015). The mineral, coal, and energy industries were mostly the terrain of foreign investors. These sectors required capital investments of the sort that domestic players were unable to provide. However, according to the World Bank, by 2012, "close to 100 percent of tin production, 95 percent of thermal coal production and 80 percent of nickel production, came from domestically owned companies" (World Bank 2015, 41).

Coal has experienced perhaps the most dramatic shift, with Indonesian tycoons competing fiercely with one another for the spoils of an industry that, at the turn of the century, became far more accessible to domestic capital. First, between 2000 and 2009, large foreign-owned coal concessions-including Rio Tinto's Kaltim Prima Coal, New Hope Mining's Adaro, BHP's Arutmin, and Korean based coal company Kideco-all entered the period in which they were contractually obliged to begin divesting to local parties (Lucarelli 2010, 30). Second, in 1997 the government introduced a new Contract of Work that favored domestically owned companies; thus, new players entering the market tended to be local. Third, the decentralization of resource management also made operations difficult for foreign investors, with unpredictable and overlapping regulations and taxes emerging across the country. The coal price was relatively low in the early 2000s as well. These factors combined to compel many foreign investors to sell down or sell out to local players (Lucarelli 2010, 30, 31). Between 2002 and 2009, over 75 percent of coal exports came from the six largest companies of which only one, PT Banpu, was majority foreign owned (Lucarelli 2010).

While the biggest coal companies came under local control in the early years of the twenty-first century, the major gold and copper companies remained in foreign hands. American, Canadian, British, and Australian companies have long dominated Indonesia's precious mineral mining industry. While some companies have engaged in divestment as per the terms of their $\mathrm{CoW}$, the overall picture is of sustained foreign domination. It is worth noting that patterns of ownership in Indonesia reflect an international trend in which Western companies dominate global metal and mineral markets, with a handful of emerging-economy mining companies growing over the past two decades (Kooroshy, Preston, and Bradley 2014). Barriers to entry are much higher in hard rock mineral mining than in coal, with larger up-front capital investments and complex technologies required to excavate through hard rock, often deep underground. Coal, on the other hand, is generally extracted from soft rock, requires less complex methods, and thus has lower barriers to entry. One longtime member of the foreign mining community in Indonesia joked in an interview that Indonesian companies were known in the industry as "surface scrapers," meaning they lacked the capacity to engage in precious mineral extraction.

Polarized ownership structures motivated local business interests to support nationalist intervention that could help expand their interests in the industry. Large foreign-owned mineral mines are increasingly seen as the next frontier for the wealthiest Indonesian businesses; they view acquiring shares in existing projects as an ideal means of entering the sector rather than via riskier exploration projects. In interviews, industry analysts regularly expressed a belief that well-connected business interests lobbied state policy makers to introduce tough divestment requirements in order to limit space for foreign 
and multinational companies and create opportunities for their own investments. Industry insiders strongly believe that the 2012 regulation requiring majority local ownership after 10 years, introduced without broad industry consultation, meant the ambitions of politically connected domestic capitalists were driving policy. ${ }^{24}$ One senior manager in a large domestic mining firm explained, "the government is preparing an environment where well-connected local businessmen can take a majority share in existing projects, taking projects mid-way." 25 This is what one former Minister referred to as "giving locals a "leg up" in a sector where foreign capital had dominated for decades. ${ }^{26}$ Another industry expert described the process as a "slow nationalization" of Indonesia's mining industry. ${ }^{27}$

Indeed, even prior to the new divestment regulations, the country's wealthiest tycoons had already begun to make their mark in these sectors by buying up existing foreign projects. For example, Aburizal Bakrie, former Chairman of the Golkar party and prominent businessman, bought into Newmont's Batu Hijau mine when the company was contractually obliged to divest. He ensured access to shares at below market price by backing a consortium of regional government enterprises. ${ }^{28}$ Other tycoons such as Eka Tjipta Widjaja, Edwin Soeryadjaya and Johan Lensa, have all entered the gold and copper industry through acquisitions and foreign divestment deals (Reuters UK 2015; Sender 2011; Tempo Bisnis 2012; Teguh Hidayat \& Partners 2015). The media and industry elites speculate that prominent politico-business elites such as Luhut Panjaitan, currently Coordinating Minister for Maritime Affairs and Natural Resources, Suryah Paloh, Chairperson of the National Democratic Party, and current Vice President Jusuf Kalla, have at different junctures pursued shares in Freeport McMoran's Grasberg mine, the largest and amongst the most profitable gold mines in the world (Cahyafitri and Witular 2015; Lubis 2015).

In July 2016, PT Medco Energy, owned by indigenous businessman and one-time PDIP politician Arifin Panigoro, acquired 82 percent of Newmont's Batu Hijau mine. Rizal Ramli, then Coordinating Minister for Maritime Affairs and Natural Resources, told the press that he approved of an acquisition that would see one of the largest mines put in the hands of an indigenous businessman: "this is important, because it has always been as though we [Indonesians] don't have the ability [to run large mines]" (Syrahrul 2015). Medco's company statements on the acquisition were heavy with nationalist rhetoric, and the company chairman stated that the transaction,

proves that with the collaboration of Indonesian companies, state-owned banks, the government and the public at large, we can solve every challenge the country faces ... [and] Newmont ... deserve[s] praise for setting a new precedent for international investors in the natural resource sector, and for being cooperative and supportive towards realizing the Indonesian people's aspiration (PT Medco Energy, 20 June 2016).

President Joko Widodo reportedly watched the Newmont acquisition carefully, hoping it may constitute a model for transferring the Freeport mine into Indonesian hands in the near future (Budiartie, Teresia, and Nasrillah 2016).

The polarized pattern of domestic and foreign ownership also meant that foreign capital constituted less of a structural constraint upon lawmakers. While the 2009 Mining Law affected the industry broadly, the divestment obligation was in fact targeted at, and would have the most impact upon, multinational companies operating in the 
precious mineral mining sub-sector. This sub-sector, while offering lucrative rents for companies and significant royalties and taxes for the government, makes only a moderate contribution to the country's overall foreign exchange and GDP in comparison to other commodities such as coal or palm oil. Copper and gold, where most foreign investment is directed, made up 0.3 and 0.4 percent of GDP in 2012. In comparison, crude palm oil constituted up to 5 percent of GDP during the boom, and 2.5 percent in the same year (See Table 1). According to the International Council on Mining and Metals, in 2010 the total production value of metallic minerals (which include gold, copper, tin, nickel, and bauxite, but not coal) reached only 1.7 percent of GDP (International Council on Mining and Metals 2012).

Groups that opposed the divestment requirements regularly cited Freeport, Vale, and Newmont's tax contributions, and the revenues that flowed to regional governments around the mine sites. But the government did not feel shackled by foreign capital and its contribution to the mining sector. Quite the opposite, in fact. Political and policy elites made private and public statements claiming that Indonesia no longer depended upon or needed foreign mining companies and that the time had come for local businesses to be the principal players in mineral extraction. For example, during the phase of implementing the divestment laws, it was common for parliamentarians, the Director General of Minerals and Coal, and industry think tanks all to assert that local companies were now "mampu," which means they were "capable" of running the sector. Cabinet ministers in Joko Widodo's cabinet (2014-) now make similar claims that Indonesians are able to run complex mining projects, and that they will do it with better contributions to state revenue and community welfare (Maskur 2014; The Jakarta Post 2015). In other words, in the eyes of senior policy makers and politicians, foreign capital constituted only a moderate structural constraint upon legislators' nationalist agenda.

Additionally, the government has maintained its pressure on Freeport and other multinational companies throughout the commodities bust since 2014-2016. Few voices call for rolling back divestment obligations or for creating more conducive conditions for companies like Freeport, Vale, Newmont, or BHP. Rather than appeasing foreign investors in light of low prices, as the market-cycle theory predicts, the Indonesian government has maintained an assertive nationalist stance. It is difficult for politicians to back down from a popular nationalist stance in this sector (Warburton 2015); but it is also the case that leading policy elites feel their bargaining power has not been reduced by post-boom conditions, and that foreign companies like Freeport are in fact more troubled by tumbling commodity prices than the Indonesian government itself (The Jakarta Post 2015). This again speaks to how lawmakers feel less constrained in their targeting of foreign capital in this sub-sector

In sum, polarized ownership structures shaped industry preferences in favor of state intervention, and local business interests cohered with the nationalist agenda of state lawmakers and parliamentarians. The sub-sector is lucrative, and during the boom an assertive class of business elites emerged with expanding interests in the new frontier of precious mineral mining. There was strong competition amongst tycoons and politicobusiness elites for access to these profitable mines, and their alliances were unstable and fractious, and remain so. But forced divestment presented them all with new investment opportunities. At the very least, interest groups supported the new divestment requirements, while some observers believe private business even drove government 
policy. Further, the mining industry's ownership structure was polarized between foreign and domestic capital, and over the past ten years foreign investment has become increasingly concentrated in the mineral mining sub-sector. While this is a hugely profitable industry, it is less strategic for Indonesia in terms of overall state revenues and economic growth. Policy makers were thus less constrained by foreign capital, and pursued a path of nationalist intervention that suited the preferences of lawmakers, politicians, and domestic business alike.

\section{THE PALM OIL SUB-SECTOR}

In Indonesia's plantations sector, the dominant palm oil sub-sector has an ownership structure that is uniquely integrated, and many of the most prominent companies constitute a blend of Malaysian, Singaporean, and Indonesian capital. The entanglement of foreign and domestic capital produced greater structural constraints upon lawmakers' nationalist agendas, and also meant local industry players had different preferences than companies in the mining sector when it came to policies targeting foreign investment. These factors undercut mobilization in the service of nationalist intervention.

Ownership structures in the palm oil industry have also undergone significant change over the past two decades. During the 1990s, palm oil was entirely closed off to foreign investors (Lindblad 2015). During this period the domestic private sector was expanding rapidly, and local companies with connections to the president and his inner circle sought protection from foreign competition. The Suharto government opened the sector again within a few years in order to improve technology and production levels, and expand the sector more generally (McCarthy and Cramb 2009). By the late 1990s, however, local companies once again began expressing frustration at having to compete with foreign investors for access to agricultural land. Domestic businesses successfully pressured the government to close palm oil to foreign investment once more in 1997 (Carson 2000, 7).

The investment regime changed again just two years later, following the Asian Financial Crisis. The International Monetary Fund's (IMF) structural adjustment program compelled the Indonesian government to liberalize parts of its economy, and roll back protectionist and anti-competitive laws in its plantations sector. American, Singaporean, and Malaysian investors took advantage of the new liberal reforms, opening up concessions and buying up bankrupt and struggling domestic companies (Jiwan 2013; Casson 2000). The 2007 Investment Law further facilitated foreign investment opportunities, allowing for up to 95 percent foreign ownership in a plantation without stipulated divestment requirements (Jiwan 2013). According to one analyst, by 2004, 2.7 million of the total 3.3 million hectares of palm oil plantation land was held by foreign investors (Jiwan 2013). By 2015, one report claimed that foreign investors held over 5 million of the total 8 million HA of dedicated palm oil lands (Adnan 2014).

However, precise figures on foreign investment are difficult to obtain and estimates vary widely. Varkkey $(2012,351)$ estimates that through joint ventures with Indonesian partners and subsidiaries, Malaysian and Singaporean investors control over two thirds of Indonesia's palm oil plantations. Sawit Watch, an Indonesian NGO, claims that after taking into account holding companies and foreign take overs of small Indonesian companies, around half of Indonesia's palm plantations are in foreign hands. The Palm Oil 
Farmers Association (Asosiasi Petani Kelapa Sawit Indonesia, or Apkasindo) claims 40 percent of palm oil concessions are foreign owned, while the body representing both foreign and domestic companies, the Indonesian Palm Oil Association (Gabungan Asosiasi Perkebunan Kelapa Sawit Indonesia, or GAPKI) estimates 30 percent of the industry is foreign owned (Harian Ekonomi Neraca 2013).

Clearly, differentiating between foreign or domestic companies in the palm oil industry is not simple. The companies that own the largest plantations are Singapore-listed Golden Agri resources, Indonesia's Salim Group, Singapore-listed Wilmar International, Malaysia-listed Sime Darby (formally Guthrie), and Jakarta-listed Astra Agro Lestari. Golden Agri Resources is listed on the Singapore stock exchange, but it is part of the Sinar Mas Group owned by Eka Tjipta Wijaya, one of Indonesia's wealthiest tycoons. Other prominent Singaporean companies with Indonesian businessmen at their helm include First Resources, Bumitami Agri, and Indofood Agri Resources (McBeth 2014). Indonesia's Fangiono family own First Resources, but the family has distanced itself from direct ownership through layers of holding companies listed in the British Virgin Islands. Wilmar International is one of the largest listed companies by market capitalization on the Singapore stock exchange, and is a joint venture between Indonesian businessman Martua Sitorus and Malaysian tycoon William Kuok. On the other hand, Jakarta-listed Astra Agro Lestari is a subsidiary of Astra International, which was set up by prominent Suharto-era Indonesian-Chinese businessman William Soeryadjaya, and is thus often perceived as an Indonesian company. But since 1999, the Jardine Matherson Group, a Hong Kong listed company, has owned a majority stake. Malaysia's Sime Darby owns over 180,000 HA of oil palm through joint ventures with Indonesian companies.

Beyond these prominent companies, there are hundreds of smaller ventures in which the shareholder structures are unclear. One industry insider revealed that the Ministry of Agriculture could only confidently ascertain the ownership of 30 percent of the private companies operating in the sector. ${ }^{29}$ The rest are "grey," and many use a system whereby an Indonesian company holds the plantation license, but is backed by Malaysian or Singaporean money. It is also common practice for an enterprise to begin with majority local ownership, and to have a well-connected Indonesian businessman at its helm; but once the Indonesian leadership has helped facilitate the licensing process, their shares will be bought out by the foreign partner. ${ }^{30}$ Farmers associations and NGOs claim that Malaysian investors favor this model. Cramb and McCarthy (2016, 445-446) explain that "interlocking ownership structures" are useful for all parties, because by working with Singaporean and Malaysian companies, Indonesian businesses can "upgrade their position within global value chains by accessing technologies and thereby improving their productivity;" meanwhile Malaysian and Singaporean companies get access to land and cheap labor.

The palm oil industry's complex ownership structure produced industry preferences distinct from those found in the mining sector, and influential Indonesian business groups lobbied against restriction on foreign capital. This is because the foreign investment cap of 30 percent and regulations on local content were set to hurt Indonesian tycoons, many of whom had established relationships with businessmen in Singapore, Hong Kong, and China, and chose to list their companies outside of Indonesia for tax purposes. One analysis suggested that the proposed legislation would negatively 
impact Malaysian and Singaporean companies like Sime Darby, Golden Agri, and Wilmar, as well as Indonesian companies with majority or large foreign ownership, like Astra Agro Lestari (Global Business Guide 2014). Observers thus questioned how the proposed cap would work in practice, given the challenge of identifying foreign investors and deciding which kind of companies it would apply to (McBeth 2014). In addition, though data are not available, if many smaller enterprises are also backed by Malaysian capital in the manner described above, it is reasonable to assume that many middle-rung businesses were also ambivalent about the regulation.

Those operating in the palm oil industry claim that the largest conglomerates in the palm oil sector have a close relationship with government elites at every level. ${ }^{31}$ Scholarly analyses similarly emphasize the importance of political connections and patronage to the expansion of the industry throughout Indonesia and Southeast Asia more broadly (Varkkey 2012; J. F. McCarthy, Gillespie, and Zen 2012; Hamilton-Hart 2015). Cramb and McCarthy $(2016,15)$ examine the industry's growth throughout Indonesia and Malaysia and note that:

A key factor [in the industry's expansion] is the common culture between Malaysia and Indonesia that facilitates the integration of business and policy elites ... [a]cross the region, patterns of political patronage remain central to the prevailing political settlements, whereby politically connected "advisors" and "commissionaries" ... are put on the company payroll ... to facilitate access to land and provide an easy path through the regulatory regime.

Indeed some observers speculated that both the MoA and Commission IV understood their proposal would upset influential domestic businesses. The clause proposing new limitations on foreign capital emerged without industry input. Journalists and industry analysts, along with companies themselves, believed the articles outlining a cap on foreign investment, mandating the use of domestic banks, and increasing local content, were intentionally inserted without wide consultation (McBeth 2014). ${ }^{32}$

The palm oil industry as a whole is also fundamental to the government's economic growth strategy, and in the eyes of the executive the economic risk of alienating both foreign and domestic investors was much higher. Agricultural commodities accounted for 12.5 percent of GDP in 2012. The vast majority of sectoral growth and revenue generation during the boom came from the palm oil industry, which has been a key driver of economic growth in Indonesia since early 2000. The Indonesian government at both the national and regional levels has embraced the global demand for palm oil. According to McCarthy and Zen, due to its "comparative advantage in terms of labor and land costs, Indonesian policy makers have long identified oil palm as a key vehicle for economic growth" (McCarthy and Zen 2016, 110). Palm oil is also one of Indonesia's most important earners of foreign exchange, for example in 2014 exports were valued at USD 17.3 billion (Aurora et al 2015). As a single commodity, its exchange earnings far outweigh those earned through the other agricultural sub-sectors and also mining sub-sectors like copper, gold, bauxite, or nickel. Expansion of the sector has also been characterized by significant engagement with smallholders and domestic labor. According to Lee et al (2014), between 2000 and 2009, the most rapid oil palm expansion in Indonesia was amongst smallholders, with annual growth rates of 11.12 percent, far higher than government estates ( 0.37 percent) and private companies (5.45 percent), indicating high levels of local and domestic engagement with the industry. It is the centrality of palm oil to 
Indonesia's export income, and its key role as a source of income for millions of Indonesian farmers, that made the executive wary of disrupting foreign investment flows and alienating domestic investors as well.

The strategic value of private capital investments, combined with the integrated flows of foreign and domestic capital, thus constituted a structural constraint upon nationalist policy agendas. When the industry lobbied against the bill, the executive listened, and the foreign investment limitations were shelved. Industry experts and media put forward various reasons for the government's decision to veto the foreign investment cap. According to GAPKI, they and the companies they represent impressed upon the government that foreign firms would simply leave and invest in other markets. ${ }^{33}$ Industry consultants also emphasized to the government that mass divestments would devalue land and undermine a key source of foreign exchange for the government (Taylor and Supriatna 2014a). Though MoA had insisted that the law would not be applied retroactively. The president was also reportedly concerned that such a policy would prompt arbitration cases from affected companies (Taylor and Supriatna 2014b).

The economic rationale put forward by industry lobbyists was similar to what foreign mining companies and industry associations argued in their opposition to the new mining divestment regime. The palm oil industry, however, had far more success. In the end, lawmakers' efforts to limit foreign investment and compel use of local content faced opposition from some of the country's wealthiest business elite, including some whose interests were enmeshed in regional networks of capital, and were thus threatened by nationalist change. Private capital also constituted a greater structural constraint in this sector, and the executive exercised more caution in their targeting of foreign capital.

\section{CONCLUSION}

This article set out to examine the empirical puzzle of why anti-foreign policy interventions emerged unevenly in different parts of Indonesia's natural resource economy. The comparative analysis of Indonesia's mining and plantations sectors points to how distinct ownership structures can constrain nationalist agendas and shape the preferences of powerful business interests, which in turn have implications for the fate of nationalist intervention.

Indonesia's mining sector is characterized by a polarized ownership structure in which the most prominent companies in the precious minerals sub-sector are demonstrably foreign owned, and domestically owned companies dominate other sub-sectors like coal, tin, and nickel. This polarization produced a convergence of preferences between state lawmakers and domestic capital in favor of reducing foreign ownership. Such convergence did not occur in the plantations sector. Ministerial and parliamentary attempts to limit foreign ownership largely failed. In the dominant palm oil sub-sector, integrated ownership structures, where Indonesian, Malaysian, and Singaporean capital are closely intertwined, means that anti-foreign interventions bump up against the interests of Indonesia's most powerful tycoons. The enmeshment of domestic and foreign capital also restricted the policy options for nationalist lawmakers in a sector that is key to the government's strategy for economic growth. The risks were greater than in the mining sector, where foreign-owned companies are more highly differentiated and concentrated in the less strategic precious minerals sub-sector. 
What has this sectoral comparison revealed about the nature of resource nationalism in Indonesia? Scholars of Indonesia's economy have long argued that resource booms tend to usher in periods of nationalist policy making. Thus, on one level, contemporary resource nationalism can be viewed as the product of an established policy-making culture within Indonesia that is statist in orientation and suspicious, even antagonistic, toward foreign capital. At the same time, this article demonstrates how policy outcomes can be contingent upon sector-level variables. In Indonesia, the preferences of an influential domestic capitalist class played a key role in determining the fate of anti-foreign policy prescriptions in both the mineral mining and plantations sectors, but in opposite directions. Established wisdom in studies of state interventionism is that distributional coalitions and rent seeking groups lobby for nationalist interventions and seek protection from foreign capital; yet in Indonesia's palm oil sub-sector, regional networks of capital complicate the boundaries of foreign and domestic, and shape business preferences in unexpected ways. Attention to sector-level political economies is, thus, crucial for understanding nationalist policy variation.

The intention here was not to depict nationalist intervention as simply the product of the private sector's preferences or its structural power. Lawmakers, politicians, and civil society activists - many of whom have no material links to the resource sectorsmobilized in favor of nationalist change in Indonesia during the boom years. Resource nationalism is fundamentally an ideological project that envisions a particular model of state-led and domestically owned resource exploitation that appeals to popular notions of resource sovereignty. During boom times, such a model looks appealing to a wide range of actors, and is pursued with greater urgency. The argument I advanced in this article is that the private sector constrains or enables the nationalist agendas of state bureaucrats and politicians, and diverts policy in different directions at the sector level.

My conclusions also challenge assumptions about how policymakers respond to booms in their most strategic resource sectors. Other studies suggest that the more strategic a sector is to a country's economy, the more states seek to control it, and the more incentives exist for state actors to pursue nationalist intervention (Haslam and Heidrich 2016a; Hsueh 2016). However, a cross-sectoral comparison of nationalist mobilization in Indonesia suggests that in the most economically vital sectors, the risk of alienating private and foreign investment is higher. Thus to the extent that vital resource sectors rely on foreign capital, lawmakers will face more significant structural constraints to their nationalist agendas.

These conclusions are particular to the Indonesian case, and are not intended as general causal claims about the conditions under which anti-foreign interventions emerge or fail in other countries. Nor is the focus on sector-level determinants intended as a substitute for macro-level analysis and cross-national comparison. Recent comparative studies provide compelling evidence that a state's regime type and its ideological orientation are good predictors of whether and how resource nationalism manifests. However, intra-state variation also requires explanation. The 'methodological nationalism' that tends to characterize the literature on resource nationalism means most studies have overlooked important variation within countries like Indonesia. One goal of this article was to bring insights from the established comparative literature on business-state relations and industrial policy into conversation with contemporary scholarship on resource nationalism. As the case of Indonesia demonstrates, a sector-level analysis offers more precise 
diagnoses of the drivers and constraints upon state interventionism, and a sharper understanding of why resource nationalism emerges in varied ways both across and within resource rich countries.

Eve Warburton is a PhD candidate in the Department of Political and Social Change at the Coral Bell School of Asia Pacific Affairs, Australian National University. Her research focuses on politics and natural resource policy in Indonesia and the Southeast Asian region, and her work has been published in South East Asia Research, The Lowy Institute, East Asia Forum, Inside Indonesia, and New Mandala.

\section{NOTES}

I am indebted to Edward Aspinall, John McCarthy, Nick Cheesman, Stephan Haggard, and two anonymous reviewers for their comments on previous iterations of this article. I also wish to thank Amy King, Evelyn Goh, and participants at the workshop, 'Unpacking the Economic-Security Nexus in Asia' at the Strategic and Defence Studies Centre, Australian National University, for their feedback on an early version of this paper.

1. A slightly different, though related, literature views nationalist intervention as the product of how statefirm relations shift over time. Vernon's influential 1971 "obsolescing bargain thesis" argues that resource nationalism emerges because of governments' changed bargaining position with private companies (Vernon 1971). States must initially offer attractive institutional arrangements to entice investors, but once those investors have sunk their capital into a resource project, the bargaining power shifts back to the government, which can then change institutional arrangements to favor the state.

2. It is worth noting here that such propositions are not particular to the Indonesian case and echo a common political economy critique of dirigiste policy making, in which interest groups, sometimes described as "distributional coalitions" or rent seekers, are perceived as key drivers of state intervention in the economy (see for example Krueger 1974; Olson 1982; Schamis 1999). Coalitions of these rent seekers, so the argument goes, organize politically to demand state protection and intervention in a specific sector for their particularistic ends rather than for the interests of the economy as a whole.

3. These same studies are equally concerned with what kinds of business-state relations produce the best growth outcomes, a question that lies beyond the scope of this current study.

4. Boschini, Pettersson, and Roine (2007), for example, argue that point source resources include both plantation crops and minerals, whereas agricultural products such as rice, wheat, and livestock are "diffuse" resources. Ross's (2001) seminal study of timber booms in Southeast Asia also shows that petroleum, mineral, and commercial plantations are all prone to price booms and busts, and that resource windfalls in these industries produce comparable responses amongst policymakers. Specifically, he argues, windfalls can prompt state and non-state actors in all of these industries (such as business groups, political clients, and rent seekers) to try and control the distribution of resource rents.

5. For further analysis of other nationalist elements in the Mining Law see World Bank 2014; Bahsin and Venkataramany 2008.

6. Interviews: former Director General of Mineral and Coal Mining, Dr. Simon Sembiring, October 20, 2013; former Director of Mineral and Coal Mining, Sukhyar, November 2, 2014.

7. There have been seven "generations" of CoW since that time, each adjusting to changed market conditions and the priorities of the state—so not all CoW were as unbalanced as Freeport's. But overall the system was considered predictable and favorable for foreign investors (Bahsin and Venkataramany 2008, 4; O'Callaghan 2010, 220).

8. Interviews: representative from the Indonesian Coal Mining Association, October 16, 2014; senior representative from the Ministry for Energy and Mineral Resources, September 25, 2014; senior mining industry consultant, Kiroyan and Partners, June 27, 2014.

9. Interviews: former Director General of Mineral and Coal Mining, Dr. Simon Sembiring, October 20, 2013; Head of the Parliamentary Working Committee for the 2009 Mining Law and PDIP politician, Sonny Keraf, May 5, 2014. The main Islamic parties also argued this line: National Mandate Party (PAN), National Awakening Party (PKB), Prosperous Justice Party (PKS) and United Development Party (PPP). PAN, for example, argued that foreign companies hold huge concessions, far more than the new law stipulates, so their contracts must be rescinded and land should be freed up so local communities can mine and enjoy benefits from mineral resources (Dewan Perwakilan Rakyat, Republik Indonesia 2008). 
10. Interview: former Director General of Mineral and Coal Mining Simon Sembiring, August 11, 2014.

11. Interviews: former Director General of Mineral and Coal Mining Simon Sembiring, October 20, 2013; former Director General of Mineral and Coal Mining Sukhyar, November 2, 2014.

12. For example, Indonesia's Bakrie Group obtained shares in Newmont's Batu Hijau mine when the company was contractually obliged to divest by establishing a partnership with a cohort of regional government owned companies (Tempo Bisnis 2010).

13. In addition, these associations were focused upon other controversial aspects of the law, including a proposal to ban the export of particular raw ores, which stood to have a direct and negative impact on local companies.

14. Interview: Former Trade Minister, Mari Pangestu, August 13, 2015.

15. Interviews: senior industry consultant, Kiroyan and Partners, October 16, 2014; senior state official at the Ministry for Energy and Mineral Resources, September 25, 2014; government relations advisor to large foreign gold mining company, September 25, 2014.

16. Interviews: deputy chairman of Parliamentary Commission IV, July 14, 2015; plantation industry consultant, September 6, 2014; representative from GAPKI, August 7, 2015.

17. Interviews: deputy chairman of Parliamentary Commission IV, July 14, 2015; plantation industry consultant, September 6, 2014; representative from GAPKI, August 7, 2015; researcher from CIFOR, August 14, 2015.

18. Interview: deputy chairman of Parliamentary Commission IV, July 14, 2015.

19. Interviews: GAPKI, August 7, 2015; Centre for International Forestry Research (CIFOR) staff August 24, 2014.

20. Interview: representative from GAPKI, August 7, 2015.

21. Ibid.

22. Interview: plantation industry consultant, September 6, 2014.

23. It is worth noting a recent case of where palm oil companies successfully mobilized together with other non-state and state actors for nationalist ends. This case concerned the Round Table on Sustainable Palm Oil. Indonesian palm oil companies opposed the transnational sustainability certification scheme, claiming it favored the interests of multinational companies and NGOs (J. McCarthy 2012). These mobilizations, however, are of a different tenor to what has been occurring in the mining sector, and have not resulted in calls for limiting foreign ownership or investment in plantations.

24. Interviews: senior industry consultant, Kiroyan and Partners, October 16, 2014; representative of the Indonesian Coal Mining Association, May 16, 2014.

25. Interview: government relations consultant for a domestic gold mining company, December 16, 2014.

26. Interview: July 13, 2015.

27. Interview: industry analyst for a foreign embassy in Indonesia, August 11, 2016.

28. State owned enterprises are, by law, given priority in divestment tenders. Bakrie financed the regional owned consortium as a means of getting access early and for a significantly low price (Alfian 2010; The Jakarta Post 2012).

29. Interview: representative from GAPKI, August 7, 2015.

30. Interview: palm oil industry consultant, January 19, 2015.

31. Interview: researcher from CIFOR, August 14, 2015; industry consultant, September 6, 2014; representative from GAPKI, August 7, 2015.

32. Interview: palm oil industry consultant, September 6, 2014.

33. Interview: representative from GAPKI, August 7, 2015.

\section{REFERENCES}

Adnan, Hanim. 2014. “Indonesia’s Oil Palm Dilemma.” The Star Online, September 27. www.thestar.com.my/ Business/Business-News/2014/09/27/Indonesias-oil-palm-dilemma-Plans-to-limit-foreign-ownership-stillundecided/. Accessed August 27, 2015.

Alfian. 2010. "Bakrie-Led Venture Picks up More Shares in Newmont.” The Jakarta Post, March 18. www. thejakartapost.com/news/2010/03/18/bakrieled-venture-picks-more-shares-newmont.html. Accessed July $24,2015$. 


\section{Eve Warburton}

Arbatli, Ekim. 2013. "Political Regimes, Investment Risk and Resource Nationalism: An Empirical Analysis." In XIV International Academic Conference on Economic and Social Development. Moscow.

Arifin, Bustanul. 2013. "On the Competitiveness and Sustainability of the Indonesian Agricultural Export Commodities." ASEAN Journal of Economics, Management and Accounting 1: 81-100.

Atkinson, Michael M., and William D. Coleman. 1989. "Strong States and Weak States: Sectoral Policy Networks in Advanced Capitalist Economies." British Journal of Political Science 19 (1): 47-67. doi:10.1017/ S0007123400005317.

Aurora, Leony, Blair Palmr, Gary Paoli, Rauf Prasodjo, and Jim Schweithelm. 2015. "Indonesia's Evolving Governance Framework for Palm Oil: Implications for a No Deforestation, No Peat Palm Oil Sector." Daemeter, http://daemeter.org/en/publication/detail/44/indonesias-evolving-governance-framework-for-palmoil-implications-for-a-no-deforestation-no-peat-palm-oil-sector\#.WXRawYgrLcs. Accessed July 23, 2017.

Bahsin, Balbir, and Sivakumar Venkataramany. 2008. "Mining Law and Policy: Replacing the 'Contract of Work' System in Indonesia." Centre for Energy, Petroleum and Mineral Law and Policy Internet Journal. www.eisourcebook.org/cms/Mining\%20Law\%20and\%20Policy\%20Evolution\%20in\%20Indonesia.pdf.

Beckmann, Rick, and Aldi Rakhmatillah. 2014. "Future Still Hazy for Indonesian Plantation Monopolies." Eco-Business, October 24. www.eco-business.com/opinion/hazy-future-indonesian-plantation-monopolies-continues/. Accessed August 27, 2015)

Benjamin, Chantelle. 2013. "Mining: Resource Nationalism All the Rage." Mail and Guardian, February 8. http://mg.co.za/article/2013-02-08-mining-resource-nationalism-all-the-rage. Accessed August 5, 2013.

Boschini, Anne D., Jan Pettersson, and Jesper Roine. 2007. "Resource Curse or Not: A Question of Appropriability." Scandinavian Journal of Economics 109 (3): 593-617.

Bremmer, Ian, and Robert Johnston. 2009. "The Rise and Fall of Resource Nationalism." Survival: Global Politics and Strategy 51: 149-158.

Bresnan, John. 1993. Managing Indonesia: The Modern Political Economy. New York: Columbia University Press.

Budiartie, Gustidha, Ananda Teresia, and Faiz Nasrillah. 2016. "Membidik Saham Batu Hijau." Tempo Magazine, April 11. https://majalah.tempo.co/konten/2016/04/11/EB/150491/Membidik-Saham-BatuHijau/07/45. Accessed May 10, 2016

Budiman, Arief. 2011. "Mining Regime in Indonesia Rejuvenated." Universitas Pelita Harapan Law Review XI (1): 51-64.

"Buletin Parlementaria." 2014. Indonesian National Parliament. www.dpr.go.id/dokpemberitaan/buletin-parlementaria/b-804-2-2014.pdf.

Cabello, Mateo, Mark Henstridge, Gustya Indriani, Smita Notosusanto, Dwi Rahardiani, and Caroline Slaven. 2013. "Indonesia: Mining White Paper.” Oxford: Oxford Policy Management.

Cahyafitri, Raras, and Rendi A. Witular. 2015. "Deal Shields Govt, Freeport from Legal Row, Corrupt Politicians." The Jakarta Post. October 16. www.thejakartapost.com/news/2015/10/16/deal-shields-govt-freeport-legal-row-corrupt-politicians.html (accessed October 23, 2015)

Carney, Richard W., and Natasha Hamilton-Hart. 2015. "What Do Changes in Corporate Ownership in Indonesia Tell Us?" Bulletin of Indonesian Economic Studies 51 (1): 123-145. doi:10.1080/ 00074918.2015.1016570.

Casson, Anne. 2000. "The Hesitant Boom: Indonesia's Oil Palm Sub-Sector in an Era of Economic Crisis and Political Change.” Occasional Paper No. 29. Center for International Forestry Research.

— Y.I.K.D. Muliastra, and Krystof Obidzinski. 2015. "Land-Based Investment and Green Development in Indonesia: Lessons from Berau District, East Kalimantan.” Center for International Forestry Research (CIFOR). www.cifor.org/library/5538/land-based-investment-and-green-development-in-indonesia-lessonsfrom-berau-district-east-kalimantan/. Accessed July 21, 2017.

Castle, James. 2014. "Indonesia's Fragile Future.” Tempo Magazine, January 5.

Chua, Christian. 2008. Chinese Big Business in Indonesia: the State of Capital. London: Routledge.

Chikwanha, Annie. 2012. "The Many Shades of Resource Nationalism." 27 November. www.saiia.org.za/ opinion-analysis/the-many-shades-of-resource-nationalism. Accessed January 27, 2014.

Cramb, Rob, and John F. McCarthy, eds. 2016. The Oil Palm Complex: Smallholders, Agribusiness and the State in Indonesia and Malaysia. Singapore: NUS Press.

Davidson, Jamie S. 2016. Indonesia's Changing Political Economy: Governing the Roads. Cambridge: Cambridge University Press. 
Dewan Perwakilan Rakyat, Republik Indonesia. 2008. "Pendapat Akhir Partai Amanat Nasional, Dewan Perwakilan Rakyat, Republik Indonesia, Terhadap Rancangan Undang-Undang Tentang Pertambangan Mineral Dan Batubara," December 16.

Domjan, Paul, and Matt Stone. 2010. “A Comparative Study of Resource Nationalism in Russia and Kazakhstan 2004-2008." Europe-Asia Studies 62 (1): 35-62. doi:10.1080/09668130903385374.

Elias, Stephen, and Clare Noone. 2011. "The Growth and Development of the Indonesian Economy." Reserve Bank of Australia, Bulletin - December Quarter. www.rba.gov.au/publications/bulletin/2011/dec/4.html.

Evans, Peter B. 1995. Embedded Autonomy: States and Industrial Transformation. Princeton: Princeton University Press.

Fairbairn, Madeleine. 2015. "Foreignization, Financialization and Land Grab Regulation.” Journal of Agrarian Change 15 (4): 581-591. doi:10.1111/joac.12112.

Frieden, Jeffry A. 1991. Debt, Development, and Democracy: Modern Political Economy and Latin America, 1965-1985. Princeton: Princeton University Press.

Gardner, David. 2013. "Not All Forms of Resource Nationalism are Alike." Financial Times, August 18. www. ft.com/content/62be6d98-05df-11e3-ad01-00144feab7de?mhq5j=e2. Accessed August 26, 2013.

Garnaut, Ross. 2015. "Indonesia's Resources Boom in International Perspective: Policy Dilemmas and Options for Continued Strong Growth." Bulletin of Indonesian Economic Studies 51 (2): 189-212. doi:10.1080/ 00074918.2015 .1061910 .

George, Alexander L., and Andrew Bennett. 2005. Case Studies and Theory Development in the Social Sciences. Cambridge: MIT Press.

Global Business Guide. 2014. "New Restrictions on Foreign Ownership of Plantations Proposed,” August 24. www.gbgindonesia.com/en/main/business_updates/2014/upd_new_restrictions_on_foreign_ownership_of_plantations_proposed.php. Accessed May 9, 2016.

Haggard, Stephan, Sylvia Maxfield, and Ben Ross Schneider. 1997. "Theories of Business and Business-state Relations." In Business and the State in Developing Countries, edited by Sylvia Maxfield, and Ben Ross Schneider. Ithaca: Cornell University Press.

Hamilton-Hart, Natasha. 2015. "Multilevel (mis)governance of Palm Oil Production." Australian Journal of International Affairs 69 (2): 164-184. doi:10.1080/10357718.2014.978738.

Harian Ekonomi Neraca. 2013. "Petani Minta Lahan Sawit Milik Asing Dibatasi," January 14. www.neraca.co. id/article/23820/petani-minta-lahan-sawit-milik-asing-dibatasi. Accessed May 9, 2015.

Haslam, Paul A., and Pablo Heidrich. 2016a. "Towards a Theory of Resource Nationalisms." In The Political Economy of Natural Resources and Development: From Neoliberalism to Resource Nationalism, edited by Paul A. Haslam and Pablo Heidrich. London: Routledge.

— eds. 2016b. The Political Economy of Natural Resources and Development: From Neoliberalism to Resource Nationalism. London: Routledge.

Herberg, Mikkal E. 2011. "Introduction.” In Asia's Rising Energy and Resource Nationalism: Implications for the United States, China, and the Asia-Pacific Region. Seattle: The National Bureau of Asian Research.

Hill, Hal, and Chatib Basri. 2004. "Ideas, Interests and Oil Prices: The Political Economy of Trade Reform During Suharto's Indonesia.” The World Economy 27: 633-655.

Hsueh, Roselyn. 2012. "China and India in the Age of Globalization Sectoral Variation in Postliberalization Reregulation." Comparative Political Studies 45 (1): 32-61. doi:10.1177/0010414011421305.

- 2016. "State Capitalism, Chinese-Style: Strategic Value of Sectors, Sectoral Characteristics, and Globalization." Governance 29 (1): 85-102. doi:10.1111/gove.12139.

Hukum Online. 2014. "Draft Bill on Plantations." 2452. Indonesian Legal Brief. http://en.hukumonline.com/ pages/lt53e8af992ee13/draft-bill-on-plantations.

Humphreys, David. 2013. "New Mercantilism: A Perspective on How Politics is Shaping World Metal Supply." Resources Policy 38 (3): 341-349.

Info Sawit. 2014. "Revisi UU No. 18 Tahun 2004 Disahkan, Asing Boleh Kuasai Kebun Nasional.” www.infosawit. com/mobile/index.php/artikel/baca/revisi-uu-no-18-tahun-2004-disahkan-asing-boleh-kuasai-kebun-nasional. Accessed August 4, 2016 (no longer available).

International Council on Mining and Metals. 2012. "The Role of Mining in National Economies.” https://www. scribd.com/doc/152190019/ICMM-Minings-Contribution-to-National-Economies.

Investor Daily. 2007. "Dampak RUU Minerba, Perusahan Tambang Asing Terbebas Kewajiban Divestasi," October 24. https://kaltimprimacoal.wordpress.com/ruu-minerba/. Accessed March 24, 2016. 
Isham, Jonathan, Michael Woolcock, Lant Pritchett, and Gwen Busby. 2005. "The Varieties of Resource Experience: Natural Resource Export Structures and the Political Economy of Economic Growth." The World Bank Economic Review 19 (2): 141-174.

Jiwan, Norman. 2013. "The Political Ecology of the Indonesian Palm Oil Industry: A Critical Analysis.” In The Palm Oil Controversy in Southeast Asia: A Transnational Perspective, edited by Bhattacharya, Jayati and Oliver Prye. Singapore: Institute of Southeast Asian Studies.

Junita, Fifi. 2015. “The Foreign Mining Investment Regime in Indonesia: Regulatory Risk under Resource Nationalism Policy and How International Investment Treaties Provide Protection." Journal of Energy \& Natural Resources Law 33 (3): 241-265. doi:10.1080/02646811.2015.1057028.

Kitschelt, Herbert. 1991. "Industrial Governance Structures, Innovation Strategies, and the Case of Japan: Sectoral or Cross-National Comparative Analysis?” International Organization 45 (4): 453-493. doi:10.1017/ S002081830003318X.

Kooroshy, Jaakko, Felix Preston, and Sian Bradley. 2014. "Cartels and Competition in Minerals Markets: Challenges for Global Governance." Chatham House the Royal Institute of International Affairs. www.chathamhouse.org/publication/cartels-and-competition-minerals-markets-challenges-global-governance. Accessed July 20, 2017.

Krueger, Anne O. 1974. "The Political Economy of the Rent-Seeking Society." The American Economic Review 64 (3): 291-303.

Kurtz, John, and James Van Zorge. 2013. “The Myth of Indonesia’s Resource Nationalism.” Wall Street Journal, October 1, sec. Opinion Asia. http://online.wsj.com/article/SB1000142405270230437310457910862207 0263560.html?mod=wsj_streaming_stream. Accessed October 3, 2013.

Lee, Janice Ser Huay, Sinan Abood, Jaboury Ghazoul, Baba Barus, Krystof Obidzinski, and Lian Pin Koh. 2014. "Environmental Impacts of Large-Scale Oil Palm Enterprises Exceed that of Smallholdings in Indonesia." Conservation Letters 7 (1): 25-33.

Lindblad, J. Thomas. 2015. "Foreign Direct Investment in Indonesia: Fifty Years of Discourse." Bulletin of Indonesian Economic Studies 51 (2): 217-237. doi:10.1080/00074918.2015.1061913.

Lubis, Uni. 2015. "Luhut, Golkar Dan Jokowi Di Pusaran \#Papamintasaham Freeport.” Rappler. www.rappler. com/indonesia/116079-luhut,-golkar-dan-jokowi-di-pusaran-papamintasaham-freeport. Accessed July 21, 2017.

Lucarelli, Bart. 2010. "The History and Future of Indonesia's Coal Industry: Impact of Politics and Regulatory Framework on Industry Structure and Performance." Working Paper, Program on Energy and Sustainable Development, Stanford University.

Mackie, Jamie. 2003. "Pre-1997 Sino-Indonesian Conglomerates, Compared with Those of Other ASEAN Countries." In Ethnic Business: Chinese Capitalism in Southeast Asia, edited by Brian C. Folk and K. S. Jomo. London: Routledge.

Manning, Chris, and Raden M. Purnagunawan. 2011. "Survey of Recent Developments.” Bulletin of Indonesian Economic Studies 47 (3): 303-332. doi:10.1080/00074918.2011.619048.

Maskur, Fatkhul. 2014. "Rizal Ramli: Jangan Takut Hadapi Freeport Dan Newmont!" Bisnis Indonesia, February 6. http://m.bisnis.com/industri/read/20140206/44/201528/rizal-ramli-jangan-takut-hadapi-freeport-dan-newmont. Accessed February 12, 2014.

Mattangkilang, Tunggadewa. 2012. "Churchill Mining Update: East Kutai Chief Not Worried About Pending \$2 Billion Suit.” Jakarta Globe, July 13. http://jakartaglobe.beritasatu.com/archive/churchill-miningupdate-east-kutai-chief-not-worried-about-pending-2-billion-suit/. Accessed July 5, 2013.

Maxfield, Sylvia, and Ben Ross Schneider. 1997. Business and the State in Developing Countries. Ithaca: Cornell University Press.

McBeth, John. 2014. "Indonesia's Plantation Bill May Undermine the Sector." The Straits Times, September 23.

McCarthy, John. 2010. "Processes of Inclusion and Adverse Incorporation: Oil Palm and Agrarian Change in Sumatra, Indonesia.” The Journal of Peasant Studies 37 (4): 821-850. doi:10.1080/03066150.2010.512460.

- 2012. "Certifying in Contested Spaces: Private Regulation in Indonesian Forestry and Palm Oil." Third World Quarterly 33 (10): 1871-1888.

McCarthy, John F., and R. A. Cramb. 2009. "Policy Narratives, Landholder Engagement, and Oil Palm Expansion on the Malaysian and Indonesian Frontiers." The Geographical Journal 175 (2): 112-123 
- Piers Gillespie, and Zahari Zen. 2012. "Swimming Upstream: Local Indonesian Production Networks in 'Globalized' Palm Oil Production." World Development 40 (3): 555-569. doi:10.1016/j. worlddev.2011.07.012.

— , and Zahari Zen. 2016. "Agribusiness, Agrarian Change, and the Fate of Oil Palm Smallholders in Jambi." In The Oil Palm Complex: Smallholders, Agribusiness and the State in Indonesia and Malaysia, edited by Rob Cramb and John F. McCarthy, 109-154. Singapore: NUS Press.

Ministry for Agriculture. 2009. "Rancangan Rencana Strategis Kementrian Pertanian Tahun 2010-2014.” www. pertanian.go.id/pug/admin/pengumuman/rancangan\%20renstra\%20deptan\%202010-2014\%20lengkap.pdf.

Ministry for Agriculture. 2013. Ministry of Agriculture Regulation No. 98 on Plantation Licensing.

Minto, Rob. 2012. “2012: The Year of Resource Nationalism?” Beyondbrics. http://blogs.ft.com/beyond-brics/ 2012/01/18/2012-the-year-of-resource-nationalism/\#axzz2O2cFeBCx. Accessed July 5, 2013.

Obidzinski, Krystof, Rubeta Andriani, Heru Komarudin, and Agus Andrianto. 2012. "Environmental and Social Impacts of Oil Palm Plantations and Their Implications for Biofuel Production in Indonesia." Ecology and Society 17 (1): 25. doi:10.5751/ES-04775-170125.

O'Callaghan, Terry. 2010. "Patience Is a Virtue: Problems of Regulatory Governance in the Indonesian Mining Sector.” Resources Policy 35 (3): 218-225. doi:10.1016/j.resourpol.2010.05.001.

Oliviera, Gustavo de L.T. 2013. "Land Regularization in Brazil and the Global Land Grab." Development and Change 44 (2): 261-283.

Olson, Mancur. 1982. "Stagflation and the Political Economy of the Decline in Productivity." The American Economic Review 72 (2): 143-148.

Patunru, Arianto, and Sjamsu Rahardja. 2015. "Trade Protectionism in Indonesia: Bad Times and Bad Policy." Lowy Institute. www.lowyinstitute.org/publications/trade-protectionism-indonesia-bad-times-and-bad-policy.

Perrone, Nicolas Marcelo. 2013. "Restrictions to Foreign Acquisitions of Agricultural Land in Argentina and Brazil.” Globalizations 10 (1): 205-209.

Raykat Merdeka Online. 2016. "Pembatasan Investasi Asing Di Perkebunan Bakal Diatur Oleh PP." http:// ekbis.rmol.co/read/2014/10/02/174347/Pembatasan-Investasi-Asing-Di-Perkebunan-Bakal-Diatur-OlehPP-. Accessed August 4, 2016.

Reuters UK. 2015. "Indonesia Energy Minister Reminds Berau to Lower Foreign Ownership.” 7 May. http://uk. reuters.com/article/2015/05/07/berau-energy-asia-resource-idUKJ9N0VC01N20150507. Accessed July 24 2015.

Ross, Michael L. 2001. Timber Booms and Institutional Breakdown in Southeast Asia. Cambridge: Cambridge University Press.

Schamis, Hector E. 1999. "Distributional Coalitions and the Politics of Economic Reform in Latin America." World Politics 51 (2): 236-268. doi:10.1017/S0043887100008182.

Schwarz, Adam. 2013. "Jakarta May Let Growth Mojo Slip Away." The Wall Street Journal Asia, September 24.

Sender, Henny. 2011. “Adaro Executives Enjoy Rise in Coal Demand.” Financial Times, July 5. www.ft.com/ int1/cms/s/0/30bb1c5e-a729-11e0-b6d4-00144feabdc0.html\#axzz3glHhqKmd. Accessed July 24, 2015.

Shafer, D. Michael. 1990. "Sectors, States, and Social Forces: Korea and Zambia Confront Economic Restructuring." Comparative Politics 22 (2): 127-150. doi:10.2307/422310.

1994. Winners and Losers: How Sectors Shape the Developmental Prospects of States. Ithaca: Cornell University Press.

Smither, James. 2013. "Sharing Spoils, or Spoiling Shares?" This Is Africa, April 23. www.thisisafricaonline. com/Analysis/Sharing-spoils-or-spoiling-shares?ct=true. Accessed July 16, 2013.

Soesastro, M. Hadi. 1989. "The Political Economy of Deregulation in Indonesia.” Asian Survey 29: 853-869.

Solomon, Michael. 2012. "The Rise of Resource Nationalism: A Resurgence of State Control in an Era of Free Markets or the Legitimate Search for a New Equilibrium?" The Southern African Institute of Mining and Metallurgy. www.polity.org.za/article/the-rise-of-resource-nationalism-a-resurgence-of-state-controlin-an-era-of-free-markets-or-the-legitimate-search-for-a-new-equilibrium-july-2012-2012-07-177.

Stainslaw, Joseph A. 2010. "Power Play: Resource Nationalism, the Global Scramble for Energy and the Need for Mutual Interdependence.” Deloitte Center for Energy Solutions.

Stevens, Paul. 2008. "National Oil Companies and International Oil Companies in the Middle East: Under the Shadow of Governments and the Resource Nationalism Cycle." Journal of World Energy Law and Business 1: $5-30$. 


\section{Eve Warburton}

Syrahrul, Yura. 2015. "Rizal Ramli Sebut Panigoro Akan Caplok 76 Persen Saham Newmont." Katadata, November 25. http://katadata.co.id/berita/2015/11/25/rizal-ramli-sebut-panigoro-akan-caplok-76-persensaham-newmont. Accessed March 21, 2016.

Taylor, Michael and Yayat Supriatna. 2014a. "Indonesia Lawmakers Draft Bill to Slash Foreign Ownership of Plantations," Reuters, August 15. www.reuters.com/article/indonesia-plantations-law-idUSL4N0QL1X620140815. Accessed March 24, 2016.

Taylor, Michael and Yayat Supriatna. 2014b. "Indonesia Passes Plantations Bill, Drops Clause on Foreign Ownership," Reuters, September 30. www.reuters.com/article/indonesia-plantations-lawidUSL3NORV23I20140930. Accessed March 24, 2016.

Teguh Hidayat \& Partners. 2015. "J Resources, Backdoor Listing with a Little Magic." www.teguhhidayat. com/2012/03/j-resources-backdoor-listing-with.html. Accessed July 24.

Tempo Bisnis. 2010. “Grup Bakrie Tergoda Tambah Saham di Newmont.” November 8. https://bisnis.tempo.co/ $\mathrm{read} /$ news/2010/11/08/088290388/grup-bakrie-tergoda-tambah-saham-di-newmont. Accessed March 23, 2016.

2012. "Surya Paloh dan Edwin Rebutan Gunung Emas," October 22. http://bisnis.tempo.co/read/news/ 2012/10/22/090437013/surya-paloh-dan-edwin-rebutan-gunung-emas. Accessed July 24, 2015.

The Economist. 2012. "Foreigners Beware." November 24. www.economist.com/news/business/21567117foreign-investors-are-getting-nervous-foreigners-beware. Accessed August 20, 2013.

The Jakarta Post. 2009. "Foreign Mining Firms Required to Divest Shares.” June 30. www.thejakartapost.com/ news/2009/06/30/foreign-mining-firms-required-divest-shares.html. Accessed August 32016.

_. 2012. "Editorial: Twist in Newmont Divestment," August 1. www.thejakartapost.com/news/2012/08/ 01/editorial-twist-newmont-divestment.html. Accessed July 24, 2015.

—. 2015. "Discourse: President Knows Well Those Orchestrating the Event: Luhut." November 20. www. thejakartapost.com/news/2015/11/20/discourse-president-knows-well-those-orchestrating-event-luhut.html.

Varkkey, Helena. 2012. "Patronage Politics as a Driver of Economic Regionalisation: The Indonesian Oil Palm Sector and Transboundary Haze." Asia Pacific Viewpoint 53 (3): 314-329. doi:10.1111/j.14678373.2012.01493.x.

Vernon, Raymond. 1971. Sovereignty at Bay: The Multinational Spread of U.S. Enterprises. London: Longman.

Vivoda, Vlado. 2009. "Resource Nationalism, Bargaining and International Oil Companies: Challenges and Change in the New Millennium.” New Political Economy 14 (4). doi:10.1080/13563460903287322.

Warburton, Eve. 2015. "Indonesia: Why Economic Nationalism Is so Popular," The Lowy Interpreter, 25 August. www.lowyinterpreter.org/post/2015/08/25/Indonesia-Why-economic-nationalism-is-so-popular. aspx.

Weiner, Robert J., and Reid W. Click. 2009. "Resource Nationalism Meets the Market: Political Risk and the Value of Petroleum Reserves.” SSRN Scholarly Paper ID 971147. Rochester, NY: Social Science Research Network. http://papers.ssrn.com/abstract=971147.

Wilson, Ernest J. 1987. "World Politics and International Energy Markets.” International Organization 41 (1): 125-149. doi:10.1017/S002081830000076X.

Wilson, Jeffrey. 2011. "Resource Nationalism or Resource Liberalism? Explaining Australia's Approach to Chinese Investment in Its Minerals Sector.” Australian Journal of International Affairs 65 (3): $283-304$. doi:10.1080/10357718.2011.563779.

—. 2015. "Understanding Resource Nationalism: Economic Dynamics and Political Institutions." Contemporary Politics 21 (4): 1-18. doi:10.1080/13569775.2015.1013293.

Winters, Jeffrey Alan. 1996. Power in Motion: Capital Mobility and the Indonesian State. Ithaca: Cornell University Press.

World Bank. 2014. "Investment in Flux." Indonesia Economic Quarterly Update. World Bank. www.worldbank.org/en/news/feature/2014/03/18/indonesia-economic-quarterly-march-2014.

—. 2015. "High Expectations." Indonesia Economic Quarterly Update. www.worldbank.org/content/dam/ Worldbank/document/EAP/Indonesia/IEQ-MAR-2015-EN.pdf.

Wright, Maurice. 1988. "Policy Community, Policy Network and Comparative Industrial Policies." Political Studies 36 (4): 593-612. doi:10.1111/j.1467-9248.1988.tb00251.x.

Zadek, Simon, Maya Forstater, Han Cheng, Jason Potts, and Gabriel A. Huppe. 2014. "Meeting China's Global Resource Needs: Managing Sustainability Impacts to Ensure Security of Supply.” Institute for Sustainable Development. www.iisd.org/sites/default/files/publications/china_supply_synthesis_report.pdf. 